\title{
ANALISIS KESULITAN PESERTA DIDIK DALAM MENYELESAIKAN SOAL-SOAL POKOK BAHASAN GARIS SINGGUNG LINGKARAN
}

\section{ANALYSIS OF STUDENT DIFFICULTIES IN SOLVING CIRCLE TANGENT PROBLEMS}

\author{
Feripadlii), Nursalam ${ }^{2}$, Sri Sulasteri ${ }^{3)}$, Suharti ${ }^{4)}$ \\ 1,2,3,4)Fakultas Tarbiyah dan Keguruan Universitas Islam Negeri Alauddin Makassar \\ feripadli@gmail.com ${ }^{1)}$, nursalam ftk@uin-alauddin.ac.id ${ }^{2}$, \\ suharti.harti@uin-alauddin.ac.id ${ }^{4}$ )
}

\begin{abstract}
Abstrak
Latar belakang penelitian ini adalah rendahnya hasil belajar matematika peserta didik terhadap pokok bahasan garis singgung lingkaran di SMP Al-Islam Benteng Tellue. Penelitian ini bertujuan untuk mengetahui kesulitan-kesulitan yang dialami peserta didik dalam menyelesaikan soal-soal pokok bahasan garis singgung lingkaran. Pendekatan penelitian yang digunakan yaitu pendekatan kualitatif yang dipadukan dengan jenis penelitian deskriptif. Subjek penelitian yaitu sebanyak 10 orang peserta didik di kelas VIII SMP Al-Islam Benteng Tellue. Pengumpulan data dilakukan dengan menggunakan metode tes dan wawancara. Data dianalisis secara deskriptif. Hasil penelitian menunjukkan kesulitan-kesulitan yang dialami peserta didik dalam menyelesaikan soal-soal pokok bahasan garis singgung lingkaran yaitu kesulitan pemahaman maksud soal yang tergolong rendah; kesulitan pemahaman konsep yang tergolong tinggi; kesulitan proses perhitungan yang tergolong rendah.
\end{abstract}

Kata Kunci: kesulitan penyelesaian soal, garis singgung lingkaran

\begin{abstract}
The background of this research is the low achievement of students' mathematics learning outcomes on the subject of circle tangent at SMP Al-Islam Benteng Tellue. This study aims to determine the difficulties experienced by students in solving the tangents to circles. The research approach used is a qualitative approach combined with a descriptive type of research. The research subjects were 10 students in class VIII SMP Al-Islam Benteng Tellue. Data was collected using the test and interview methods. Data were analyzed descriptively. The results of the study indicate that the difficulties experienced by students in solving the questions of the tangent line of the circle are the difficulties in understanding the meaning of the questions are classified as low; the difficulty of understanding the concept is high; the difficulty of the calculation process is low.
\end{abstract}

Keywords: solving problems difficulty, circle tangent

How to Cite: Feripadli, Nursalam, Sulasteri, S., \& Suharti. (2021). Analisis kesulitan peserta didik dalam menyelesaikan soal-soal pokok bahasan garis singgung lingkaran. Al asma: Journal of Islamic Education, 3(2), 232-241.

\section{PENDAHULUAN}

Pendidikan merupakan salah satu aspek yang cukup berperan penting dalam peningkatan kualitas sumber daya manusia. Perbaikan kegiatan belajar mengajar harus diupayakan secara optimal agar mutu pendidikan dapat meningkat . Ini mutlak dilakukan karena majunya pengetahuan dan teknologi berimplikasi pada meluasnya cakrawala 
berfikir manusia terdidik sesuai dengan tuntutan zaman. Oleh karena itu, guru harus berupaya dalam memelihara maupun mengembangkan minat atau kesiapan belajar peserta didik. Seorang guru menempatkan peserta didik lebih banyak belajar sendiri dan mengembangkan aktivitasnya dalam pemecahan masalah.

Mengingat bahwa matematika adalah salah satu mata pelajaran yang diujikan dalam ujian nasional, guru sebagai pendidik haruslah mencermati hal tersebut, karena kenyataan menunjukan bahwa terdapat sejumlah peserta didik yang mengalami kesulitan dalam menyelesaikan soal-soal matematika dibandingkan dengan mata pelajaran lain (Utami, 2017). Hal ini terbukti menjadi salah satu alasan mengapa prestasi keseluruhan dalam matematika dianggap cukup rendah. Pernyataan ini didukung oleh hasil penilaian PISA (Programme for International Student Assessment) terhadap tingkat kemampuan siswa berusia 15 tahun dalam menyelesaikan soal-soal PISA yang termasuk dalam soal kategori higher order thinking skills (HOTS). Berdasarkan laporan OECD (2018) yaitu Organisasi Kerja Sama Ekonomi dan Pembangunan yang menaungi Programme for International Student Assessment melaporkan bahwa skor rata-rata matematika siswa Indonesia hanya mencapai 379 dengan skor rata-rata OECD sebesar 487. Pada laporan tersebut, posisi Indonesia berada pada kuadran low performance dengan high equality. Hal ini perlu menjadi bahan perhatian guru untuk mengembangkan kemampuan siswa dalam memecahkan permasalahan matematis.

Pemecahan masalah merupakan salah satu aspek utama dalam pelajaran matematika yang di perlukan siswa untuk menerapkan dan mengintegrasikan konsepkonsep matematika dan keterampilan (Kristianingsih \& Ratu, 2019). Rendahnya prestasi peserta didik dalam bidang matematika merupakan ketidakmampuan peserta didik dalam memecahkan masalah karena peserta didik belum menguasai materi pelajaran (Syafi'i, Marfiyanto, \& Rodiyah, 2018). Hal ini tampak pada pemberian tes yang sedikit berbeda dari contoh soal, dimana peserta didik mengalami kesulitan dalam menyelesaikan soal tersebut.

Berdasarkan hasil wawancara yang dilakukan dengan guru yang bertanggung jawab atas mata pelajaran matematika di SMP Al-Islam Benteng Tellue Kabupaten Bone, diperoleh informasi bahwa pada umumnya siswa di sekolah tersebut kurang mampu dalam menyelesaikan masalah, terutama yang berkaitan dengan garis singgung lingkaran. Terbukti pada hasil belajar siswa untuk materi garis singgung lingkaran masih banyak peserta didik yang tidak mencapai nilai KKM. Menurut Zulhayadi (2019) bahwa salah satu gejala siswa mengalami kesulitan belajar dapat dilihat pada pencapaian hasil belajar.

Kesulitan belajar dapat diartikan sebagai suatu kondisi dalam suatu proses balajar yang ditandai adanya hambatan-hambatan tertentu untuk mencapai hasil belajar (Darsa, Nasir, \& Rusydi, 2020). Dalam proses belajar mengajar, guru sangat diperlukan untuk mengatasi kesulitan peserta didik dalam menyelesaikan soal-soal matematika agar tidak terjadi kesalahan. Namun guru tidak dapat mengambil keputusan dalam membantu peserta didiknya yang mengalami kesulitan menyelesaikan soal-soal matematika jika guru tidak tahu di mana letak kesulitannya. Oleh karena itu, seorang guru perlu mengetahui kesulitan peserta didik dalam belajar matematika dan juga mengetahui penyebabnya. Jika hal ini kurang mendapat perhatian maka akan menyebabkan peserta didik kesulitan dalam mempelajari materi selanjutnya yang berhubungan dengan garis singgung lingkaran, karena materi ini merupakan materi prasyarat untuk materi matematika di tingkat yang lebih tinggi, seperti pada materi persamaan garis singgung lingkaran di SMA. 
Sejalan dengan pendapat Sirri, Ratnaningsih, dan Mulyani (2020) bahwa kesulitan belajar matematika pada peserta didik berhubungan dengan kemampuan belajar yang kurang sempurna, kekurangan tersebut dapat terungkap dari penyelesaian persoalan matematika yang tidak tuntas atau tuntas tetapi salah, ketidaktuntasan tersebut dapat diduga karena kesalahan penggunaan konsep dan prinsip dalam menyelesaikan persoalan matematika yang diperlukan. Selain itu, Saleh, Husniati, dan Gaffar (2021) menyatakan bahwa kesulitan belajar yang dialami siswa menunjukkan adanya kesenjangan atau jarak antara prestasi akademik yang dicapai oleh siswa pada kenyataannya (prestasi aktual). Beberapa penelitian telah mengungkapkan kesulitan-kesulitan yang dialami siswa dalam menyelesaikan soal matematika, diantaranya penelitian Dwidarti, Mampouw, dan Setyadi (2019) menyimpulkan bahwa baik siswa yang memiliki kemampuan matematika tinggi maupun sedang, masih mengalami kesulitan dalam menyelesaikan soal, yaitu kesulitan memahami konsep, menerapkan prinsip dan keterampilan.

Bertitik tolak dari uraian tersebut sehingga penulis tertarik melaksanakan penelitian dengan judul; “Analisis Kesulitan Peserta Didik dalam Menyelesaikan Soal-Soal Pokok Bahasan Garis Singgung Lingkaran pada Peserta Didik Kelas VIII SMP Al-Islam Benteng Tellue Kabupaten Bone".

\section{METODE PENELITIAN}

Jenis penelitian ini adalah penelitian kualitatif, yaitu penelitian yang bermaksud untuk memahami fenomena tentang apa yang dialami oleh subjek penelitian misalnya perilaku, persepsi, motivasi, tindakan, secara holistik dengan cara deskripsi dalam bentuk kata-kata atau bahasa pada suatu konteks khusus yang alamiah dan dengan memanfaatkan berbagai metode alamiah. Sedangkan metode penelitiannya adalah deskriptif, yaitu penelitian yang berusaha untuk mendeskripsikan suatu gejala peristiwa atau kejadian secara sistematis dan akurat mengenai sifat-sifat populasi atau daerah tertentu. Penelitian ini dilaksanakan di SMP Al-Islam Benteng Tellue Kabupaten Bone. Penelitian ini merupakan penelitian kualitatif sehingga subjek penelitian yang digunakan untuk mendapatkan data tidak dipilih secara acak tetapi dilakukan secara selektif sesuai dengan tujuan yang ingin dicapai dalam penelitian ini, yaitu untuk mengetahui kesulitan apa dan seberapa besar tingkat kesulitan yang dialami peserta didik dalam menyelesaikan soal garis singgung lingkaran. Seluruh peserta didik di kelas VIII SMP Al-Islam Benteng Tellue Kabupaten Bone yang menjadi subjek penelitian. Sebanyak 10 orang peserta didik di kelas VIII SMP Al-Islam Benteng Tellue Kabupaten Bone.

Fokus penelitian ini adalah kesulitan-kesulitan apa saja yang dialami peserta didik dan seberapa besar tingkat kesulitan yang dialami peserta didik dalam menyelesaikan soalsoal pokok bahasan garis singgung lingkaran pada peserta didik kelas VIII SMP Al-Islam Benteng Tellue Kabupaten Bone. Sedangkan objek penelitian yang akan dianalisis ditinjau dari 3 aspek, yaitu: Pemahaman maksud soal, Pemahaman konsep, dan Proses perhitungan.

Teknik pengumpulan data yang digunakan dalam penelitian ini adalah tes tertulis dan wawancara. Data penelitian yang berupa jawaban responden atas soal yang diberikan pada peserta didik, tiap jawaban yang diberikan peserta didik dianalisa kesalahankesalahannya. Selanjutnya kriteria yang digunakan untuk menentukan kategori skor kesulitan yang diadopsi dari kategori penguasaan matematika adalah skala lima. Setelah data hasil tes diperoleh, kemudian dilakukan wawancara untuk melengkapi informasi data 
yang diperoleh dari hasil tes. Maka data wawancara yang dikumpulkan akan dianalisis melalui tiga tahapan, yaitu 1) reduction (reduksi data); 2) display (penyajian data); 3) conclusion drawing/verification (penarikan kesimpulan/verifikasi).

\section{HASIL DAN PEMBAHASAN}

Berikut ini disajikan kesulitan yang dialami peserta didik dengan mengalisa hasil tes peserta didik. Dari hasil tes tersebut terlihat letak kesalahan serta penyebab untuk menentukan kesulitan yang dialami peserta didik. Dalam penelitian ini diambil 5 peserta didik yang dianalisis jawabannya.

a. Analisis Kesulitan Peserta Didik Nomor Subjek 10

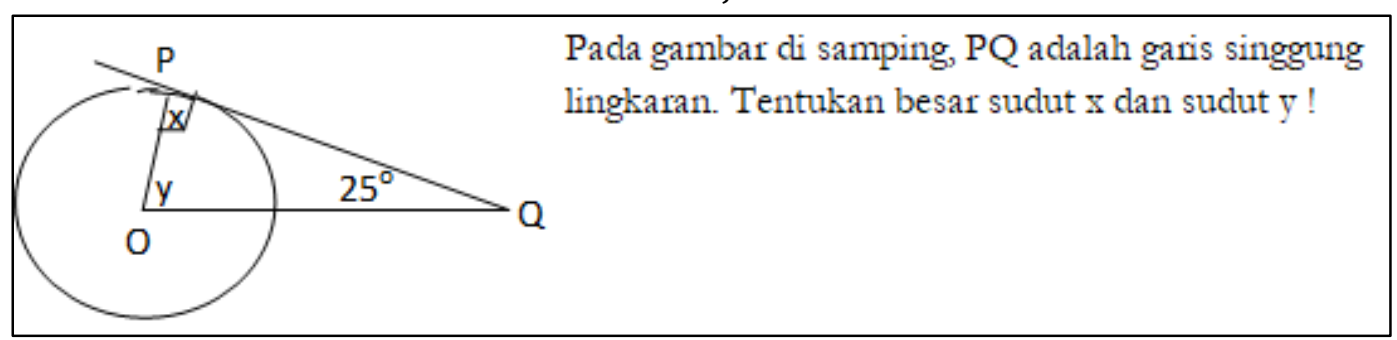

Gambar 1. Soal Nomor 1

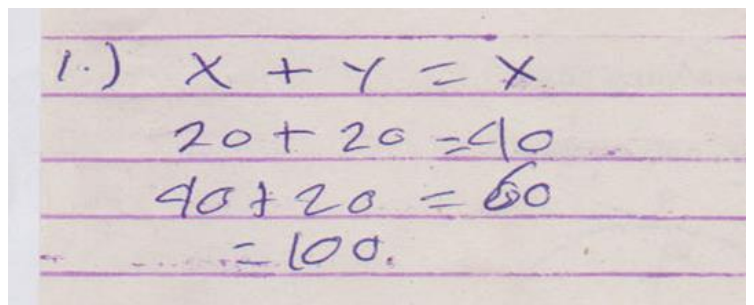

Gambar 2. Jawaban Peserta Didik

Berdasarkan jawaban dari peserta didik, dapat diketahui bahwa peserta didik tidak memahami apa yang ditanyakan soal. Hal ini tampak pada jawabannya dimana peserta didik dalam menjawab soal asal menjawab saja. Dapat juga diketahui peserta didik tidak teliti dalam membaca apa yang ditanyakan soal karena dalam menjawab soal peserta didik menjawab tidak sesuai dengan apa yang ditanyakan pada soal. Selain itu peserta didik juga tidak mengetahui bahwa $\triangle O P Q$ adalah segitiga siku-siku. Hal ini dapat diketahui karena peserta didik tidak mengetahui besar sudut $\mathrm{x}$ adalah $90^{\circ}$.

Hasil wawancara menunjukkan bahwa peserta didik asal menjawab soal saja. Selain itu peserta didik juga tidak tahu $\triangle O P Q$ adalah segitiga siku-siku. Hal ini disebabkan karena peserta didik tidak mengerti apa yang ditanyakan pada soal, peserta didik juga belum paham tentang konsep dasar segitiga dan jenis-jenis segitiga serta besar sudut pada segitiga. 
b. Analisis Kesulitan Peserta Didik Nomor Subjek 4

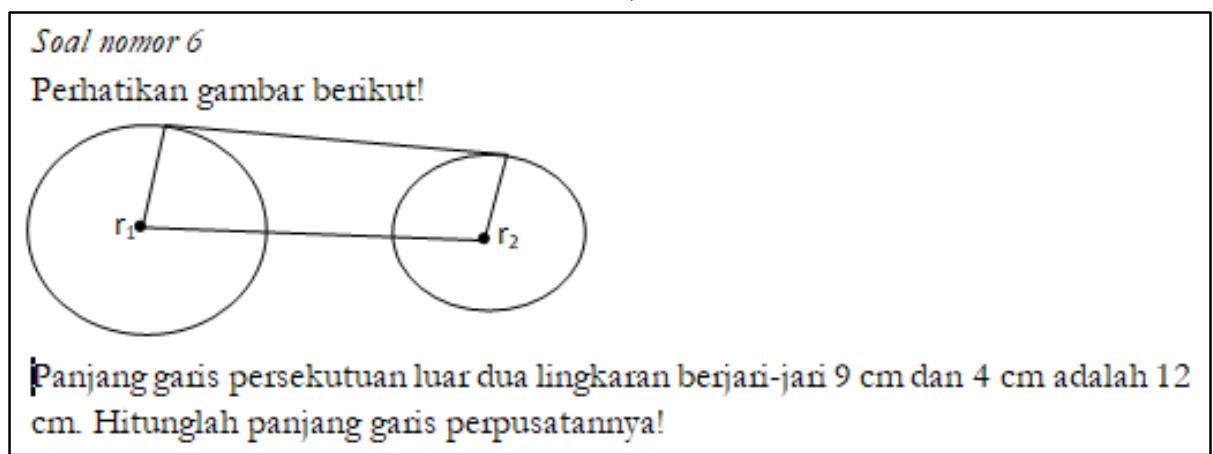

Gambar 3. Soal Nomor 6

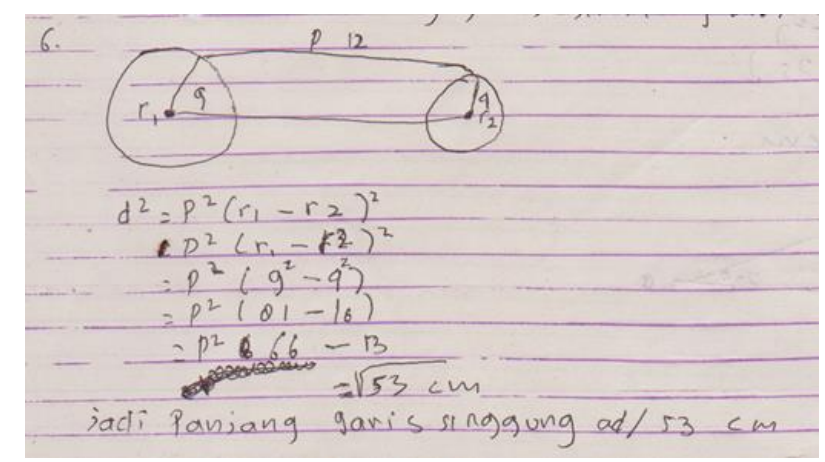

Gambar 4. Jawaban Peserta Didik

Berdasarkan jawaban dari peserta didik, dapat diketahui bahwa peserta didik tidak teliti dalam membaca apa yang diketahui dan ditanyakan soal. Hal ini tampak pada jawaban peserta didik dimana peserta didik salah dalam membuat sketsa gambar. Peserta didik mengirah $12 \mathrm{~cm}$ itu adalah panjang garis perpusatannya padahal itu adalah panjang garis persekutuannya. Peserta didik juga tidak teliti menuliskan rumus garis singgung persekutuan luar dua lingkaran. Hal ini tampak pada jawaban peserta didik dimana ia menuliskan rumus garis singgung persekutuan luar dua lingkaran adalah $d^{2}=p^{2}\left(r_{1}-r_{2}\right)^{2}$ , padahal rumus yang benar adalah $d^{2}=p^{2}-\left(r_{1}-r_{2}\right)^{2}$. Selain itu, tampak juga bahwa peserta didik sulit dalam menyederhanakan bentuk akar. Hal ini tampak pula pada jawaban peserta didik dimana peserta didik mengirah bahwa tetap 53 juga.

Hasil wawancara menunjukkan bahwa peserta didik tidak teliti dalam membaca apa yang diketahui dan ditanyakan soal. Peserta didik juga tidak teliti menuliskan rumus garis singgung persekutuan luar dua lingkaran. Peserta didik juga sulit dalam menyederhanakan bentuk akar.

c. Analisis Kesulitan Peserta Didik Nomor Subjek 8

Soal nomor 5

Panjang jari-jari dua lingkaran masing-masing $5 \mathrm{~cm}$ dan $7 \mathrm{~cm}$.jarak kedua pusatnya $13 \mathrm{~cm}$. Hitunglah panjang garis singgung persekutuan dalamnya!

Gambar 5. Soal Nomor 5 


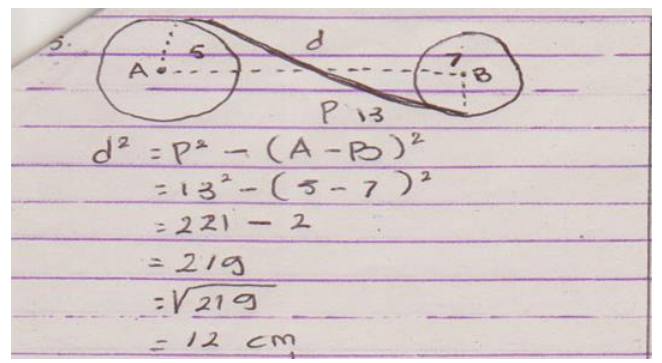

Gambar 6. Jawaban Peserta Didik

Berdasarkan jawaban dari peserta didik, dapat diketahui bahwa peserta didik salah dalam menggunakan rumus dimana ia menggunakan rumus garis singgung persekutuan luar untuk mencari panjang garis singgung persekutuan dalam. Peserta didik juga salah dalam menyelesaikan bentuk pangkat. Hal ini tampak pada jawabannya dimana peserta didik beranggapan bahwa padahal. Selain itu, peserta didik juga salah dalam menyederhanakan bentuk akar, hal ini tampak pada hasil pekerjaannya dimana peserta didik mengira .

Hasil wawancara menunjukkan bahwa peserta didik salah dalam menggunakan rumus. Peserta didik juga salah dalam menyelesaikan bentuk pangkat. Selain itu peserta didik juga salah dalam menyederhanakan bentuk akar. Hal ini dikarenakan rendah pemahaman peserta didik tentang materi tersebut serta rendah keterampilan peserta didik dalam mengoperasikan bentuk bilangan akar dan pangkat.

d. Analisis Kesulitan Peserta Didik Nomor Subjek 9

\section{Soal nomor 9 \\ Dua lingkaran A dan B masing-masing berdiameter $36 \mathrm{~cm}$ dan $16 \mathrm{~cm}$. Jika jarak $A B$ adalah $26 \mathrm{~cm}$, berapa panjang garis singgung persekutuan luar kedua lingkaran tersebut?}

Gambar 7. Soal Nomor 9

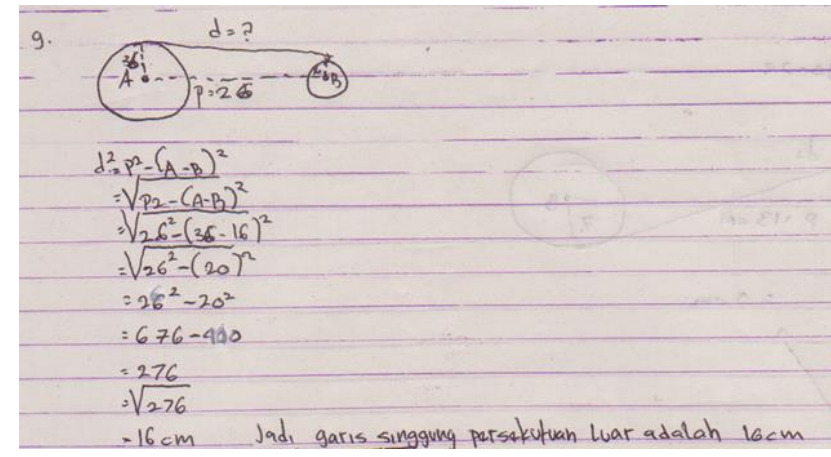

Gambar 8. Jawaban Peserta Didik

Berdasarkan jawaban dari peserta didik, dapat diketahui bahwa peserta didik salah dalam menerapkan rumus garis singgung persekutuan luar. Hal ini tampak pada jawabannya dimana peserta didik sudah benar menggunakan rumus tetapi dalam tahap proses pengerjaan soal peserta didik salah dalam menentukan besar jari-jari lingkaran $\mathrm{A}$ dan B. Peserta didik mengirah lingkaran A jari-jarinya adalah $36 \mathrm{~cm}$ dan lingkaran B jarijarinya adalah $16 \mathrm{~cm}$. padahal yang diketahui pada soal adalah diameternya berarti jari-jari 
lingkaran A adalah $18 \mathrm{~cm}$ dan jari-jari lingkaran B adalah $9 \mathrm{~cm}$. selain itu peserta didik juga salah dalam menyederhanakan bentuk akar dimana peserta didik mengirah $\sqrt{219}=12$.

Petikan wawancara menunjukkan bahwa peserta didik salah dalam menerapkan rumus garis singgung persekutuan luar. Hal ini tampak pada jawabannya dimana peserta didik sudah benar menggunakan rumus tetapi dalam tahap proses pengerjaan soal peserta didik salah dalam menentukan besar jari-jari lingkaran A dan B. Selain itu peserta didik juga salah dalam menyederhanakan bentuk akar dimana peserta didik mengirah $\sqrt{276}=16$. Hal ini terjadi karena rendahnya pemahaman dasar peserta didik tentang lingkaran dimana peserta didik tidak mengetahui bahwa diameter itu adalah $\frac{1}{2} r$, peserta didik kurang teliti dalam membaca apa yang diketahui pada soal, serta peserta didik kurang terampil dalam menyederhanakan bentuk akar.

e. Analisis Kesulitan Peserta Didik Nomor Subjek 2

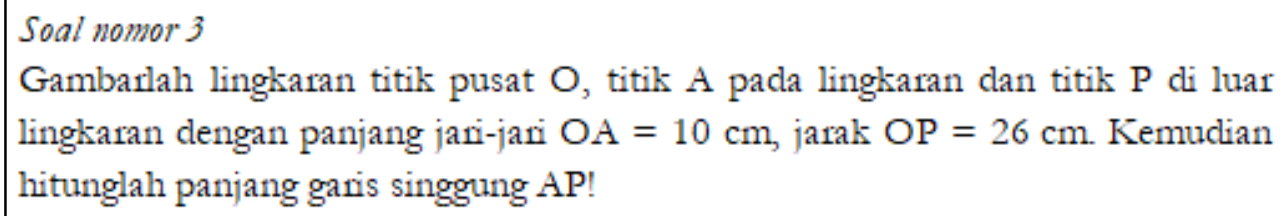

Gambar 9. Soal Nomor 3

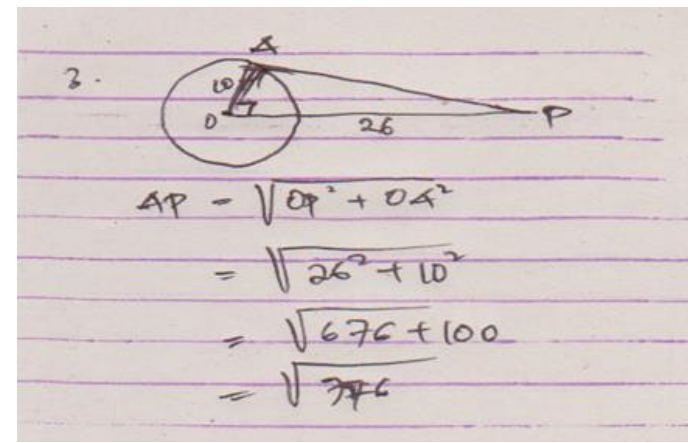

Gambar 10. Jawaban Peserta Didik

Berdasarkan jawaban dari peserta didik, dapat diketahui bahwa peserta didik salah dalam menerapkan rumus Phytagoras. Hal ini tampak pada jawabannya dimana peserta didik mengirah garis singgung AP adalah sisi miringnya. Sehingga peserta didik menuliskan rumus $A P=\sqrt{O P^{2}+O A^{2}}$ padahal sisi miringnya adalah OP jadi rumus yang benar adalah $A P=\sqrt{O P^{2}-O A^{2}}$.

Hasil wawancara menunjukkan bahwa peserta didik salah dalam menerapkan rumus Phytagoras. Hal ini tampak pada jawabannya dimana peserta didik mengirah garis singgung AP adalah sisi miringnya. Sehingga peserta didik menuliskan rumus $A P=$ $\sqrt{O P^{2}+O A^{2}}$ padahal sisi miringnya adalah OP jadi rumus yang benar adalah $A P=$ $\sqrt{O P^{2}-O A^{2}}$. Hal ini terjadi karena peserta didik hanya sekedar menghapal rumus saja tetapi tidak memahami konsep Phytagoras dengan baik. 
Berdasarkan hasil validasi data yang dilakukan, diperoleh tiga tipe kesulitan yang dialami peserta didik dalam menyelesaikan soal-soal pokok bahasan garis singgung lingkaran, yaitu tipe I kesulitan pemahaman maksud soal, tipe II kesulitan pemahaman konsep, dan tipe III kesulitan proses perhitungan. Secara ini, berikut ini dijelaskan kesulitan-kesulitan yang dialami peserta didik serta penyebabnya dengan mengacu pada kesalahan dari peserta didik.

\section{a. Tipe I (Kesulitan Pemahaman Maksud Soal)}

Berdasarkan hasil perhitungan diperoleh persentase kesulitan peserta didik yang mengalami kesulitan tipe I (aspek kesulitan memahami maksud soal) sebanyak 35\%. Kesulitan tipe I ini tergolong rendah.

Kesulitan tipe I merupakan kesulitan dalam memahami maksud soal. Hasil tes yang dilakukan menunjukkan bahwa peserta didik mengalami kesulitan dalam memahami apa yang ditanyakan soal, tidak teliti dalam membaca apa yang ditanyakan soal, dan salah dalam membuat sketsa gambar berdasarkan apa yang diketahui soal. Gejala tersebut merupakan gejala kesulitan peserta didik dalam memahami maksud soal. Hasil ini sejalan dengan yang dikemukakan oleh Elvina, Safrudin, Wahyuningsih, dan Rusdin (2021) bahwa peserta didik yang tidak dapat memahami soal dengan baik akan mengakibatkan kesalahan dalam menyelesaikan soal tersebut.

\section{b. Tipe II (Kesulitan Pemahaman Konsep)}

Berdasarkan hasil perhitungan diperoleh persentase kesulitan peserta didik yang mengalami kesulitan tipe II (aspek kesulitan pemahaman konsep) sebanyak 42\%. Kesulitan tipe II ini tergolong cukup tinggi.

Kesulitan tipe II merupakan kesulitan pemahaman konsep. Hasil tes yang dilakukan menunjukkan bahwa peserta didik tidak memahami sifat-sifat garis singgung lingkaran, sudut yang dibentuk oleh garis yang melalui titik pusat dan garis singgung lingkaran, salah dalam menggunakan dan menerapkan rumus Phytagoras, salah dalam menggunakan dan menerapkan rumus garis singgung pesekutuan dalam, serta luar. Permasalahan kesulitan peserta didik dalam pemahaman konsep perlu menjadi perhatian dan dicari solusinya karena menyelesaikan masalah-masalah matematika perlu ditekankan pada pengertian tentang permasalahan yang dihadapi peserta didik dan pemahaman tentang konsep yang terkandung dalam persoalan matematika tersebut. Dewi, Untu, dan Dimpudus (2020); Utari, Wardana, dan Damayani (2019) menjelaskan bahwa peserta didik yang tidak memahami konsep dengan baik akan mengakibatkan kesulitan dalam menyelesaikan soal.

\section{c. Tipe III (Kesulitan Proses Perhitungan)}

Berdasarkan hasil perhitungan diperoleh persentase kesulitan peserta didik yang mengalami kesulitan tipe III (aspek kesulitan proses perhitungan) sebanyak 23\%. Kesulitan tipe III ini tergolong rendah.

Kesulitan tipe III merupakan kesulitan proses perhitungan. Hasil tes yang dilakukan menunjukkan bahwa peserta didik salah dalam menyederhanakan bentuk akar, peserta didik salah dalam menyelesaikan bentuk pangkat, dan peserta didik salah dalam proses penjumlahan. Saputri, Ningsih, dan Widyawati (2017); Wulandari dan Setiawan (2021) mengemukakan bahwa ada beberapa kesalahan peserta didik dalam mengerjakan soal-soal 
matematika dan salah satunya adalah kesalahan hitung. Kesalahan hitung adalah kesalahan dalam menghitung matematika seperti menjumlahkan, mengurangi, mengalikan, dan membagi. Penelitian Zainudin, Utami, dan Noviana (2021) menyatakan bahwa kesalahan perhitungan terjadi karena kurangnya ketelitian siswa dalam mengerjakan soal.

Oleh karena itu, beberapa cara untuk mengatasi kesulitan tersebut agar tidak terjadi kesalahan kembali diuraikan sebagai berikut:

1) Dalam pembelajaran matematika guru hendaknya mampu menjelaskan konsepkonsep matematika kepada peserta didik dengan bahasa yang sederhana. Jika memang diperlukan guru dapat menggunakan alat peraga matematika, karena dengan bantuan alat peraga yang sesuai dengan pokok bahasan yang diajarkan, konsep matematika akan lebih mudah dipahami oleh peserta didik. Dengan demikian peserta didik akan mudah memahami ide dasara suatu konsep atau membuktikan suatu konsep.

2) Dalam mengajarkan konsep matematika diperlukan kemampuan guru untuk mengaitkan konsep, prinsip, serta keterampilan dengan pengalaman sehari-hari peserta didik yang diperoleh dari alam sekitarnya. Jika diperlukan guru dapat menggunakan perumpamaan atau lata peraga yang mudah dijangkau dan murah serta secara tepat dapat menggambarkan situasi yang ada.

3) Guru melibatkan peserta didik dalam membuat generalisasi. Guru menuntun peserta didik untuk mampu membuat kesimpulan berdasarkan sifat-sifat khas dari suatu situasi yang diberikan. Kekurangan-kekurangan yang masih terdapat dalam diri peserta didik dalam membuat generalisasi perlu ditanggapi secara positif sehingga peserta didik semakin terpacu untuk mampu memperoleh jawaban yang tepat.

4) Guru menyampaikan dengan jelas bagaimana cara menghitung yang benar untuk menyelesaikan suatu soal.

5) Guru perlu lebih banyak memberikan latihan soal yang menekankan pada penerapan rumus dan menekankan pemahaman konsep secara jelas dalam melakukan proses pembelajaran.

\section{SIMPULAN}

Berdasarkan hasil penelitian dan pembahasan sebelumnya, maka diperoleh beberapa kesimpulan yaitu, (1) Kesulitan yang dialami peserta didik kelas VIII SMP Al-Islam Benteng Tellue Kabupaten Bone dalam menyelesaikan soal pokok bahasan garis singgung lingkaran terdiri dari tiga aspek yaitu aspek kesulitan tipe I (kesulitan pemahaman maksud soal), tipe II (kesulitan pemahaman konsep), dan tipe III (kesulitan proses perhitungan); (2) Tingkat kesulitan peserta didik kelas VIII SMP Al-Islam Benteng Tellue Kabupaten Bone dalam menyelesaikan soal pokok bahasan garis singgung lingkaran yang mengalami kesulitan dalam memahami maksud soal tergolong rendah, yang mengalami kesulitan dalam pemahaman konsep tergolong cukup tinggi, dan yang mengalami kesulitan dalam proses perhitungan tergolong rendah.

\section{DAFTAR PUSTAKA}

Darsa, D. Y., Nasir, M., \& Rusydi. (2020). Analisis kesulitan peserta didik dalam menyelesaikan soal-soal kalor menggunakan teori Polya di SMA Negeri 3 Banda Aceh. Jurnal Phi: Jurnal Pendidikan Fisika Dan Fisika Terapan, 2019(2), 5-10. 
Dewi, N. K., Untu, Z., \& Dimpudus, A. (2020). Analisis kesulitan menyelesaikan soal matematika operasi hitung bilangan pecahan siswa kelas VII. Jurnal PRIMATIKA, $9(2), 61-70$.

Dwidarti, U., Mampouw, H. L., \& Setyadi, D. (2019). Analisis kesulitan siswa dalam menyelesaikan soal cerita pada materi himpunan. Journal Cendekia: Jurnal Pendidikan Matematika, 03(02), 315-322.

Elvina, A., Safrudin, N., Wahyuningsih, \& Rusdin, M. E. (2021). Analisis kesalahan peserta didik dalam menyelesaikan persamaan garis singgung lingkaran. Jurnal Birunimatika, 1(1), 13-22.

Kristianingsih, R., \& Ratu, N. (2019). Kemampuan pemecahan masalah siswa menyelesaikan soal materi garis singgung lingkaran 1. AKSIOMA: Jurnal Matematika Dan Pendidikan Matematika, 10(2), 135-142.

OECD. (2018). Programme For International Student Assessment (PISA) Result From PISA 2018. http://www.oecd.org/pisa/

Saleh, A. N. Al, Husniati, A., \& Gaffar, A. (2021). Analisis kesulitan menyelesaikan soal matematika materi pola bilangan ditinjau dari perbedaan gender siswa kelas VIII SMP Negeri 34 Makassar. SIGMA: Jurnal Pendidikan Matematika, 13(20), 19-25.

Saputri, S., Ningsih, E. F., \& Widyawati, S. (2017). Analisis kesulitan anak tunagrahita dalam menyelesaikan soal operasi penjumlahan di sekolah luar biasa (SLB) harapan ibu metro. MaPan : Jurnal Matematika Dan Pembelajaran, 5(2), 187-200.

Sirri, E. L., Ratnaningsih, N., \& Mulyani, E. (2020). Analisis Kesulitan peserta didik dalam menyelesaikan soal kemampuan berpikir reflektif matematis ditinjau dari tipe kepribadian. Journal of Authentic Research on Mathematics Education (JARME), 2(1), 46-56.

Syafi'i, A., Marfiyanto, T., \& Rodiyah, S. K. (2018). Studi tentang prestasi belajar siswa dalam berbagai aspek dan faktor yang mempengaruhi. Jurnal Komunikasi Pendidikan, 2(2), 115. https://doi.org/10.32585/jkp.v2i2.114

Utami, N. D. (2017). Kesulitan pada siswa kelas xi dalam menyelesaikan soal geometri ditinjau dari level berpikir. Universitas Muhammadiyah Surakarta.

Utari, D. R., Wardana, M. Y. S., \& Damayani, A. T. (2019). Analisis kesulitan belajar matematika dalam menyelesaikan soal cerita. Jurnal Ilmiah Sekolah Dasar, 3(4), 534-540.

Wulandari, M., \& Setiawan, W. (2021). Analisis kesulitan dalam menyelesaikan soal materi barisan pada siswa sma. JPMI: Jurnal Pembelajaran Matematika Inovatif, 4(3), 571578. https://doi.org/10.22460/jpmi.v4i3.571-578

Zainudin, M., Utami, A. D., \& Noviana, S. (2021). Analisis kesulitan siswa dalam menyelesaikan soal peluang ditinjau dari koneksi matematis. Suska Journal of Mathematics Education, 7(1), 41-48.

Zulhayadi. (2019). Analisis kesalahan siswa dalam memahami konsep persamaan garis singgung lingkaran di kelas VIII SMP Negeri 1 Muarasipongi. Insttitut Agama Islam Negeri. 